\title{
Chapter 1 \\ Migration of Ukrainians to the European Union: Background and Key Issues
}

\author{
Olena Fedyuk and Marta Kindler
}

\subsection{Introduction}

Ukrainians form one of the largest groups of all third-country nationals living and working in the European Union (EU), yet in the contemporary research environment, their migration to the EU goes unnoticed, and Ukrainians are seen mainly as one of the "migrant groups" in studies concerning Central and Eastern European migrants. Why has this subject been studied so little? Or has it been studied, but without stirring wider public or political interest? This volume brings together a team of scholars from a range of disciplines to trace the dynamics of Ukrainian migration and its research over the last three decades and to provide a comprehensive overview of the available literature on Ukrainian migration to the EU.

Ukrainian migration to the EU is interesting for contemporary migration studies for four reasons. First, it is the largest of all post-USSR migratory movements to the EU and thus a trend-setter for migrants from the post-Soviet space, who use their experience of the Soviet past as a form of social capital in migration. Second, with over 300,000 first residence permits issued to nationals of Ukraine in 2014, ${ }^{1}$ they provide a valuable case for comparative studies of third-country nationals' mobility across the EU, as well as across a great variety of occupational and legal statuses. Third, Ukrainian migration responds keenly to the gendered demand of particular

The original version of this chapter was revised. An erratum to this chapter can be found at DOI 10.1007/978-3-319-41776-9_14

${ }^{1}$ http://ec.europa.eu/eurostat/statistics-explained/index.php/Residence_permits_statistics

O. Fedyuk $(\bowtie)$

Marie Curie Changing Employment ITN, University of Strathclyde, Glasgow, UK

e-mail: olena.fedyuk@strath.ac.uk

M. Kindler

Centre of Migration Research, University of Warsaw, Warsaw, Poland

e-mail: marta.kindler@uw.edu.pl 
labour sectors in the receiving countries; migrations from Ukraine are highly feminized in some cases, and in others the gender ratio is more or less equal. Analysis of the emergence and development of these gendered migration streams opens up a very important perspective on a larger debate of precariousness and gendering of work in the EU. Finally, migrants from Ukraine engage in a wide range of transnational practices. All these aspects justify the need for an in-depth and more systematized look at up-to-date knowledge of these complex migrations.

Ukraine provides a rich case study to explore how geopolitical changes in Europe change and shape migration. The raising of the Iron Curtain in the early 1990s opened a new chapter in the mobility of Ukrainian nationals, marked by the ability to leave the country and return, a right denied to citizens of the Soviet era. Ukraine's geopolitical role has been further determined by its location between the EU's eastern border and Russia, and on the route of several important gas pipelines connecting Russia and the EU. Over the last 25 years it has been a country of turbulent transformations, with social developments resulting not only in the overthrow of governments and changes of leadership but also in the creation of new groups of precarious and marginalized people unable to pursue their professional and economic activities in Ukraine. This has led to a variety of individual histories and mobility flows that are constantly changing in the face of contemporary political and economic factors. Thus the military action that started in 2014 in the east of Ukraine and the breakaway of Luhansk and Donetsk regions, as well as a dramatic political and economic reallocation of resources following the Maidan protests of 2014, is likely to lead to a reconfiguration of economic and humanitarian migration. Understanding these processes in a historical context, and linking past and current forms of mobility makes the state-of-the-art form of this volume a fruitful and timely exercise.

Ukrainian migration did not begin with the emergence of the independent Ukrainian state in 1991. It is rooted in pre-World War I migrations from the territories of present-day Ukraine, and is influenced by the experience of the massive Soviet-era forced relocations of populations, labour migration and movements for socialist projects (such as the construction of the power plants in the east of Ukraine or the cultivation of the Virgin Lands in Russia). Ukrainian migration research uses the term "fourth-wave migration", to describe economically driven migration from post-independence Ukraine. The term, hardly familiar among researchers outside Ukraine, has an important symbolic role, not only in the positioning of recent migration in the historical and political context of the last two centuries, but also in the nation-state-building project of independent Ukraine. To understand the latter, it is necessary to look at the proposed classification in more detail. The first wave is identified as the movements of the rural population that started in the last decades of the twentieth century and lasted until World War I. In response to the political and economic oppression experienced by the Ukrainian population under Russian and Austro-Hungarian imperial rule, large numbers from Eastern Ukraine migrated to Siberia and the Altai, while those from Western Ukraine went to the Americas (particularly the USA, Canada, Argentina and Brazil) (Lopukh 2006). 
Similar directions of migration occurred in the second wave in the inter-war period, and the third wave includes post-World War II and the socialist mobilization projects of the 1950s and 1960s (Shybko et al. 2006). This wave classification occupies a prominent position in Diaspora Studies (Wolowyna 2013; 2010), which often identify the reasons for the first three waves of migration in the political turmoil and oppression of the relevant period. The beginning of the fourth wave of migration labour migration - is attributed by Shybko et al. (2006) to the socio-economic changes that occurred in Ukrainian society after 1991, such as restructuring of the post-Soviet economy and labour markets, the significant rise in unemployment, long delays in payments of salaries, and currency and wage inflation. What distinguishes the first three waves is that they are described as politically driven, while the fourth one is economic and social in nature.

The "four waves" perspective poses a number of controversies. It not only depoliticizes the events that followed Ukrainian independence, reducing them to simple economic transformations, but it also omits the history of economically driven migration by individual workers and groups (Bedezir 2001; Černík 2006) throughout the Soviet era. Such were, for example, the seasonal and other forms of circular migration of the 1970s and 1980s to oil-rich regions of the USSR, the main purpose of which was to increase the consumption power of individuals and households. The "historical wave" approach is part of an important state-building political exercise that involves migration research in the rewriting of Ukrainian history following decades of Soviet ideological domination. In our view, the "four waves" approach provides an important historical perspective that stretches across the emergence and dissolution of the state's borders and migration regimes, notably the division of Ukrainian territory between Poland, the Austro-Hungarian Empire, Romania and, of course, the Soviet Union. However, in selectively elevating certain population movements over others, the "four waves" represents an ideological construction of migration research that ignores the Ukrainian population's high level of mobility during the Soviet era. The symbolic importance of this perspective has inspired the methodological approach in this volume - mapping the research analyzing migration and the ideologically informed agendas that have shaped it in different national and disciplinary arenas.

\subsection{Placing Ukrainian Migration Research in a Broader Context}

Contextualizing migration to the EU in the larger picture of migration from Ukraine, it is important to note that estimates of the number of Ukrainians worldwide differ greatly. The major difference lies in the way Ukrainian migrants are defined in Russia. Data from 2002, where the country of birth is the defining criterion, give the number of Ukrainians in Russia as 3,559,975, which accounts for $66.7 \%$ of Ukrainians living in the major destination countries (5,335,840 in total, circa 2012; 
MPC 2013). In 2010 the nationality criterion used by Russian statistics shows 93,390 Ukrainian residents. In this case the total size of the migrant population in major receiving countries drops to $1,869,255$ persons, leaving Russia with $5 \%$ of the total stock while the USA becomes the top destination country hosting $18.8 \%$ of Ukrainians living abroad (351,793 persons), followed by Poland with $12.2 \%$ (227,446 persons). The USA gains even more significance when self-identification, rather than place of birth or nationality, are considered. Throughout the 1980s there were 716,780 persons declaring Ukrainian ancestry living in the USA. Their number increased by $29 \%$ in the 2000 s to reach 931,297 in 2010 , constituting $0.3 \%$ of the total US population. ${ }^{2}$ The declared ethnic origin criterion puts Canada third largest in the world, after Ukraine and Russia, in terms of Ukrainian population. According to the 2011 National Household Survey (NHS), Ukrainian Canadians number $1,251,170$ (3.7\% of the country's population) and are mainly Canadianborn citizens. Ukrainian Canadians are the ninth-largest ethnic group in Canada. Meanwhile, Ukrainian emigration stocks in Canada were equal to 59,460 persons in 2006, ranking them far below the USA and Israel (258,793 in 2005) (MPC 2013, table 1). The EU as a whole, with over one million Ukrainians $(1,052,184)$ when defined according to country of birth, has a share of $19.7 \%$, while when defined according to country of nationality $-56.3 \%$.

The two current main destinations for Ukrainian migration are the EU and the Russian Federation. By 2013 third-country nationals constituted 4\% (20.4 million) of the total EU population. Ukrainians rank top among non-EU citizens, with 303,000 first residence permits in 2014. The most common reason for third-country nationals entering the EU is family (family reunion or formation), with the highest numbers of permits issued in Italy and Spain, and the second is education, with the UK leading. These permits are in general easier to access than labour migration permits. However, Ukrainians stand out from this picture, with employment-related permits (issued to 206,000 persons) the main category of entry and Poland (81\% of all Ukrainians receiving permits in 2014) the main destination country with approximately $30 \%$ more than in $2013 .{ }^{3}$ It is also important to note that in 2014 , the largest increase relative to 2013 among the 30 main citizenship groups of asylum applicants in the EU28 was recorded for Ukrainians.

Contemporary migration of Ukrainian nationals to the European Union began in the mid-1990s (although statistics did not reflect this until the early 2000s) with migration to the countries of Southern Europe - Italy, Spain and Portugal - but also to countries in Western Europe with a historical legacy of migration, such as Germany. Ukrainians were migrating in the early 1990s to Central and Eastern Europe (mainly Poland and Czech Republic), but these countries were not EU member states at the time. Unlike the temporary stay (less than a year) that used to characterize migration within Central and Eastern Europe, the temporal character of migration to Southern Europe began to include uninterrupted stays of 2 years or

\footnotetext{
${ }^{2}$ http://navihator.net/articles/view/id/128; http://www.inform-decisions.com/stat/index.php?r=immig/verimmig

${ }^{3} \mathrm{http} / / /$ ec.europa.eu/eurostat/statistics-explained/index.php/Residence_permits_statistics
} 
more. It also started to involve further mobility within the European Union, as Ukrainian nationals entered one country in order to move to another, without returning to Ukraine. Since 2008, migrants have tended to choose labour markets that have been less affected by the economic crisis and those that view migrant workers from Ukraine favourably. Very little return from EU countries has been registered among Ukrainian migrants (see Chaps. 10, 11 and 12).

Among important EU destination countries for Ukrainian migrants, Germany stands out with its profile due to large ethnic resettlement programmes. Of the top twenty foreign populations in Germany in 2011, Ukrainian nationals with a residence permit ranked twelfth with a total of 124,293 (BMI 2011). There were also about 205,000 German nationals with a Ukrainian immigration background in 2011 (Destatis 2012), who were largely ethnic German resettlers or Jewish migrants from Ukraine. The biggest growth in ethnic German resettlers took place between 1991 and 2004, amounting to an average of 3000 newly arrived people per year (Bpb 2011). Initially family members amounted to $20-30 \%$ of all repatriates from Ukraine (BMI 2004; BMI 2013, Wirz unpublished). Currently, the next most significant reason for Ukrainian migration to Germany in terms of numbers is family reunification (BAMF 2012a). 1441 Ukrainian labour migrants with a work permit entered Germany in 2011 (BAMF 2012a). Additionally, the majority of au pairs from CIS countries in Germany come from Ukraine; there were 1155 Ukrainian au pairs in 2010 (BAMF 2012b). A total of 396 Ukrainian IT specialists entered Germany from 2000 to 2004 under a special arrangement (BMI 2004) and a very small group of other labour migrants - only a few per year - includes self-employed and highly qualified Ukrainian nationals (BAMF 2012a, Wirz unpublished). In recent years, there has been a growth in the outsourcing of IT and human resources management to the EU through multinational corporations' networks, and this represents yet another turn in the dynamics of Ukrainian labour mobility. The transformations in the dynamics of migration are triggered not only through Ukrainian relations with the EU (such as the EU visa liberalization action plan for Ukraine, local border traffic agreements between Ukraine and neighbouring countries, and bilateral agreements on social security). They are also shaped through geopolitical transformations of the whole region, such as the expansion of the EU, which has strongly impacted ties with many neighbouring countries, and the changing political situation in Ukraine (for a more detailed discussion see Chap. 4).

Placing the migration of Ukrainians to the EU in a broad context, we identify six significant developments: first, the legacy of Soviet-era spatial mobility in current patterns of Ukrainian migration; second, the ongoing recession and increasing political instability in the country of origin; and third, the labour demand in particular sectors of receiving EU countries. The type of jobs taken by immigrants in the receiving countries is accompanied, on the one hand, by the introduction of restrictions on settlement of third-country nationals, and on the other, by the creation of new channels for temporary labour migrants. A fourth factor is the absence of legal protection for citizens of the country of origin (in particular, the lack of effective bilateral agreements with receiving countries that would guarantee transfers of pensions and other social benefits). Fifth is the increase in women's independent labour 
migration and related changes in, and reinforcement of, particular gender roles. There are state-specific, largely economic, variations in these developments, including the effects of the 2008 economic crisis, and the state's current and past migration policies, as well as the current European political and ideological crisis in the face of rising refugee waves. Finally, the volume also briefly relates to developments in Ukraine since the 2013 political upheaval, the Maidan movement and the military conflict that followed.

To a great extent contemporary Ukrainian migration to the Russian Federation is a continuation of the internal labour migration of the USSR. ${ }^{4}$ According to Shulga (2002), many migrants continue to regard migration to Russia as internal movement, perceiving the border as transparent. Temporal and circular trips of one to 3 months are the dominant pattern (Libanova et al. 2009). The absence of language barriers and extensive social networks in Russia facilitate their integration and Ukrainian migrants "dissolve into the crowd" (Shulga 2002: 283) as an unremarkable group. While official data suggest that in 2010 there were 200,000-300,000 Ukrainian labour migrants in Russia, the unofficial estimates stand at between 800,000 and 3,000,000 (Tegler and Cherkez 2011), as a large share of the labour migrants do not work officially. Over $70 \%$ of all Ukrainian migrants to Russia are men (Tegeler and Cherkez 2011). The majority work in the construction sector (Libanova et al. 2009), which has been heavily affected by the 2008 economic recession (Sylina 2008). Further changes in these migration patterns can be expected following the 2014 annexation of Crimea by Russia and the ongoing war. Such changes will reflect the links with Russia among segments of Ukrainian society, as well as the nationality-based safety networks in the EU established through migration after Ukrainian independence. This volume offers a useful insight into the continuities and disruptions of migration research around the dissolution of the USSR.

Another destination country for Ukrainian migration is Turkey. By 2012, $3,839,852$ Ukrainians had arrived in Turkey (Içduygu 2013). Ukrainian nationals are exempt from visas for travel to Turkey for up to 60 days. Since the 1990s, it has been one of the key destinations for so-called "shuttle traders" (Shulga 2002) and temporary labour migrants, with Ukrainian women working primarily in the domestic sector, textiles, restaurants and the sex industry (Akalin 2007; Içduygu 2006), while men work in the agricultural sector (Içduygu 2006). Like migrants in the EU, a number of Ukrainian migrants who enter Turkey through official channels slip into undocumented status by continuing their stay after their visas expire (Kirişci 2009). In 2012, Ukrainians were among the top five nationalities of visa overstayers (864 people were apprehended). However, the main form of irregularity is unofficial work. In 2012 over 7500 residence permits were granted to Ukrainian nationals (Içduygu 2013). ${ }^{5}$

Migration from Ukraine to Israel, the USA and Canada is different in nature. Ukrainian nationals primarily migrate to Israel to settle, arriving either within the framework of the return programme for people of Jewish background and their

\footnotetext{
${ }^{4}$ We would like to thank Victoria Volodko for her contribution to this section. ${ }^{5}$ ibid.
} 
family members (the Law of Return) or via family reunification. ${ }^{6}$ Between 1990 and 2003 approximately 950,000 migrants (many of them highly educated) arrived in Israel from the former Soviet Union (FSU), which constituted 17\% of Israel's total population (Walsh and Tartakovsky 2011). Data on Ukrainian migrants is usually presented as part of the FSU migration. Although according to some sources migrants from the former Soviet Union have been quickly absorbed into the middle class of Israeli society (Kimmerling 1998, cited in Al-Haj 2002), it has been noted that as a group they seek cultural uniqueness (Ben-Rafael et al. 1998, cited in Al-Haj 2002), with the Ukrainian Jewish youth in Israel having created a particular transnational culture (Golbert 2001). As research has shown, demographic concentration in terms of residential patterns is accompanied by relatively closed social networks and the ethnic component is central for self-identification (Al-Haj 2002).

Long-term settlement migration is also a characteristic of post-Soviet emigration from Ukraine to the USA and Canada (see also Chap. 2). The number of Ukrainians in the USA is steadily increasing. Migrants who arrived in the period 1997-2007 made up 68\% $(190,000)$ of all persons with Ukrainian ancestry in the USA (Wolowyna 2010). A large number of those migrants were under 18. What is also important to note is that a significant share, especially in the 1990s, constituted Ukrainian Jews. This among others contributes to the increasing number of Russianspeaking persons of Ukrainian ancestry in the USA. However, new migration (post1991) has increased the number of Ukrainian speakers by 60\% (Wolowyna 2010). The main class of entrants between October 2013 and September 2014 (the dominant trend since 2007) were immediate relatives of a US citizen, with a total of 8193 Ukrainian nationals admitted. ${ }^{7}$ The majority of people of Ukrainian ancestry live in the states of New York, Pennsylvania and California. ${ }^{8}$

Since 1991, a modest but growing number of immigrants have come to Canada from Ukraine, largely due to Ukraine's political and economic instability. Between 1991 and 2001, 23,435 Ukrainian nationals migrated to Canada (Makuch 2003). From 2004 to 2013, 23,623 Ukrainian nationals became new permanent residents in Canada. ${ }^{9}$ Ukrainian migrants who arrived after 1991 were attracted by the opportunities available in the labour market, but they show a low level of social integration with the "old" Ukrainian diaspora in spite of their interest in Ukrainian businesses (Makuch 2002). The total Ukrainian ethnic community in Canada amounts to 328,250 persons and has formed over 500 charitable organizations (mainly religious) (Couton 2013). Post-Soviet Ukrainian migration to Canada is characterized by the high professional status of the newcomers (Hudyma 2011). However, as in the case of migration to the EU, migrants in general do not work in their own profession, but instead find employment in unskilled or low-skilled sectors.

\footnotetext{
${ }^{6} \mathrm{http} / / /$ www.keepeek.com/Digital-Asset-Management/oecd/social-issues-migration-health/international-migration-outlook-2014/israel_migr_outlook-2014-22-en\#page 1

${ }^{7} \mathrm{http} / / / \mathrm{www}$. inform-decisions.com/stat/index/php?r=site/page\&view=inmig_ukr

${ }^{8} \mathrm{http}: / / \mathrm{www}$. inform-decisions.com/stat/index.php?r=site/page \&view=showmaps $\&$ map=usa ukrs.jpg

${ }^{9} \mathrm{http} / /$ www.thecanadianencyclopedia.ca/en/article/ukrainian-canadians/
} 


\subsection{Contributions to This Book}

The contributions to this book aim to engage in a critical dialogue with existing knowledge; although each chapter in our volume confirms the proliferation of research about Ukrainian migration in a number of disciplines, this research has been highly unsystematic, patchy and often politicized. There is a vast discrepancy in methodologies, data sets that are not comparable and an absence of longitudinal approach. This volume seeks to map out existing research in a variety of disciplines, analyzing its proliferation in certain areas and entering into a constructive debate with the literature as to the development of the research trajectories, the politics of knowledge production and need for further studies.

\subsubsection{Part I: Continuities and Changes in Ukrainian Migration: An Analytical Review of Literature}

The first part opens with a historical perspective often missing from the study of Ukrainian migration. Olena Malynovska and Bastian Vollmer address the long preSoviet and Soviet history of labour migration from Ukrainian territory, which is repeatedly dismissed in the analysis of more recent, post-independence migration. The authors trace changes not only in migratory patterns but also in scholarly production of knowledge about migration as affected by ideological fashions past and present. The economic analysis of migration of Ukrainian nationals by Olga Kupets in Chap. 3 looks at the impact of the changing economic situation in Ukraine and in migration destination countries - among others the temporal demand of particular labour market sectors. It appraises the evidence on the labour market performance of Ukrainians working temporarily abroad. Monika Szulecka, in Chap. 4, reviews Ukrainian migrants' dynamic changes of administrative status and the opportunities linked to such transformation, along with academic discourses on different aspects of irregularity in migrants' entry, stay or work. The author also analyzes laws and policies relevant to Ukrainian migrants in various receiving states.

A separate chapter is dedicated to Ukrainian migration research from a gender perspective. Gendered migration has gained visibility and politicization not only in the discourse of states but also in civil society and academia. The recent military events in Ukraine are forcing further consolidation of traditionalist (patriarchal) values and discourses and male/female dichotomies in Ukrainian society, leaving very little space for a variety of women's lived experiences and strategies. Chapter 5 by Olena Fedyuk emphasizes the lack of gender perspectives in virtually all disciplines that provide a perspective on Ukrainian migration in this volume and introduces an open debate on gender as a focal political construction in studying Ukrainian migration. Normative gendered discourse and practices serve to shame and control migrants and their families, influence remittance flows, and extend state-making and church-building exercises. Part I ends with a chapter by Agata Górny and Marta 
Kindler, who study theoretical and empirical approaches to temporality and the study of time-dependent aspects of Ukrainian migration. The authors attempt to identify lessons learned from observation of Ukrainian spatial movements as regards causes and consequences of the temporariness of their international mobility.

The five different dimensions that guide the analysis of Part I of this volume are also reflected in the analyses of data and literature concerning Ukrainian migration to selected EU countries in Part II. A degree of repetition is inevitable, as the authors analyzing the different dimensions draw on the same studies that are reviewed in the country chapters. It is worth noting that one dimension is not addressed separately integration. The integration of Ukrainian migrants is mentioned in specific chapters (see Chaps. 7, 8, 11 and 12).

\subsubsection{Part II: Ukrainian Migration to Selected EU Countries: Facts, Figures and the State of the Literature}

The second part of the book provides an overview of data and literature available on the migration of Ukrainian nationals to six EU countries: Poland, Czech Republic, Greece, Italy, Portugal and Spain. This part allows for a focus on the contrasts and commonalities of the migration linking Ukraine to Central European countries (Czech Republic and Poland) and Southern European countries (Greece, Italy, Portugal and Spain). It is difficult to compare data from the different countries, with such large discrepancies in the availability, as well as the quality, of statistical data on migration. We decided, nevertheless, to arrange the country chapters according to geographical regions.

Migration to Southern European countries intensified in the early 2000s, at a later stage of the Ukrainian migration to the EU. Although, in general, in all of these countries Ukrainian migrants originating from the western part of Ukraine predominate, the Southern European destination countries had a significant share of migrants from Kiev. We can arrange the countries in sub-groups, with the changing gender balance of Ukrainian migration initially showing a clear predominance of women migrants to Italy and Greece. However, we are also aware of cross-country similarities between the regions, with the economic crisis, especially felt in the construction sector, having to a great extent halted the migration of Ukrainians to Portugal and the Czech Republic. The effects on migration of such occurrences as the Maidan and the ongoing military conflict are yet to be studied, but in Poland there is a clear rise in terms of all entry channels for Ukrainian migrants, while returns which had been occurring since the economic crisis from such countries as Greece stopped. The chapters in this part of the volume capture the complexity of the same group of migrants arriving at and moving between different destinations at different moments in time, and provide a necessary background to identify future research agendas.

Starting with Ukrainian migration to Poland, Chap. 7, written by a team of scholars, Zuzanna Brunarska, Marta Kindler, Monika Szulecka and Sabina Toruńczyk-Ruiz, discusses the character of this migration flow and stock and addresses the changes 
that have occurred in the last two decades in what the authors term a "local" form of mobility. This local character, visible from highly temporary (even less than a month) circular movement before Poland's EU accession through to a continuation of circulation, although less frequent, in the post-2004 era, is certainly a unique characteristic of Ukrainian mobility to this country. However, as the authors note, the political changes in Ukraine are a milestone in the changing face of migration to Poland, with the number of settlement permit applicants clearly on the rise, but accompanied by a rise in all channels of entry, including asylum applicants. A step ahead on the journey from temporary labour migrants toward a settled and well-integrated minority is the Czech Republic, analyzed thoroughly by Yana Leontiyeva in Chap. 8. Leontiyeva notes, however, that although Ukrainian migrants do form the largest minority, their inflow to the Czech Republic practically stopped in 2008, due to the worsening of the situation in the country's labour market.

Marina Nikolova and Michaela Maroufof in Chap. 9 provide an overview of Ukrainian migration to Greece, which like other Southern European countries was known for its large-scale emigration, but with the fall of the Soviet Union became a country receiving immigrants from Central and Eastern Europe, including Ukrainians. Characterized by a large informal economy and a seasonal tourist industry, Greece had a significant need for a temporary labour force. However, it is currently undergoing the worst economic recession in recent history, with decreasing rates of employment and income, a skyrocketing public debt and loans from the IMF and EU all affecting migration patterns. Francesca Alice Vianello, who writes on Ukrainian migration to Italy in Chap. 10, first provides background information on Italy as receiving country, setting Ukrainian migrants within the broader context of immigrant groups. She takes a gender approach to her analysis, however, focusing on the feminized character of this migration and offering a description of the most typical profiles of Ukrainian migrant women present in Italy.

Ukrainian migration to Portugal, having no historical links, was sudden and very intense. Chapter 11 by Maria Lucinda Fonseca and Sónia Pereira analyzes the sudden development of this migration, and how Ukrainians have integrated in the country. The authors point to the changes, similar to those noted in the chapter on Greece, from (mainly irregular) labour migration to family reunification and study as the main motives for entry. Mikołaj Stanek, Renáta Hosnedlová and Elisa Brey provide an accurate assessment of the key data sources regarding Ukrainians in Spain in Chap. 12, pointing to its shortcomings and putting forward proposals for improvement. As in Portugal, the migration to Spain had no historical links and was unexpected. Stanek and colleagues critically review the current literature on this migrant group and identify conceptual gaps, such as the need for clarity in the notion of integration, for future comparative research.

The final Chap. 13 of this volume by Cinzia Solari goes beyond Ukrainian migration to the European Union, providing the reader with a comparison of Ukrainian migrants in Rome and Los Angeles. This chapter identifies some of the points of comparison, such as transnational activity of migrants and their impact on the sending country, the role of gender in this process and the differing patterns of Ukrainian migration to the European countries presented in the volume and to the 
USA. Methodologically the close-up ethnographic account of this chapter distinguishes it from the rest of the volume and suggests yet another operational possibility for current and future comparative studies.

\subsection{Key Issues}

This book provides the reader with knowledge on migration of one of the important third-country national groups to the European Union. It navigates around the existing patchwork of steadily growing research on migration of Ukrainian nationals to the EU by providing critical analysis of up-to-date available sources and linking historical and contemporary texts to establish the continuity of migratory trends and practices.

The volume's analysis reveals the durability and continuous transformation of migration from Ukraine, with continuing temporariness of labour migrants on one hand and increasing numbers deciding to reside longer abroad on the other, and at the same time some evidence that settlement allows them to circulate. The volume points to differences between receiving states, not only as regards entry channels such as the difference between receiving residence permits for work reasons (Poland) and for family reasons (Spain) - but also as regards the labour market situation, where discrepancies remain between earnings in Central and Southern Europe, the latter being more attractive and facilitating actual settlement. Notably, members of ethnic minorities can be found in more senior positions in the labour market in countries with a longer immigration history than those in Central Europe. Interestingly, in those countries that were predominantly receivers of temporary Ukrainian migrants and that do not facilitate access to residence, as is the case in Poland, settlement seems to be gaining significance.

The volume also reflects on the reasons for progress or silences in certain areas. Progress has been made regarding the main trends and patterns of migration from the economic and legal perspectives, insights into practices in particular qualitative research, such as those concerning migrant domestic work, and theoretical approaches, such as the transnational perspective. Areas not addressed include internal differences within Ukrainian migrant groups in the different countries. Too often the groups are treated in research as a single "block", while significant differences can be found in their socio-economic backgrounds, levels of education, generation and how these are linked to reasons for migrating and migration practices. There is almost no critical gender perspective in the analysis, with most of the studies focusing on Ukrainian women migrants. Almost nothing is known about secondgeneration Ukrainian migrants. A critical study of the civic engagement of Ukrainians settling in the EU is also missing, especially in the light of the ongoing events in Ukraine. We also know little, apart from data on remittances, and the general consequences of the increasing depopulation and population ageing of Ukrainian society, about the impact of Ukrainian migration on Ukraine's development. Also, to what extent have the receiving societies changed due to the 
appearance of a new migrant group, especially in countries like Spain or Portugal where it occurred so suddenly?

This book illustrates national differences in data availability and reliability. The basic concepts underlying international statistics - such as the categories used to define an international migrant - continue to vary across the different countries. When it comes to cataloguing migrants by their legal status, Ukrainians can be an exemplary case study of the fluidity and imperfections of the latter and of how legal status affects people's access to mobility, social security and employment. Population census and data sources on residence cards in a number of countries often underestimate the actual number of Ukrainian migrants staying in a given country. In Poland, for example, as in numerous countries, the majority of Ukrainians stay based on visas and do not apply for residence cards. While population registers at the national level are used to produce international statistics on migration in Spain, the Polish population register cannot be used for such purposes as it lacks crucial basic information, such as the place of residence, and there are no population registers in Portugal. The data collection system reflects the need to control for migration of third-country nationals, with more importance attached to particular movements of foreign citizens by the respective countries, and not as much on having all-EU comparative, reliable data on immigrants and emigrants. A further aspect is the statistics available in the country of migrant origin, Ukraine, where a systematic quantitative approach is practically non-existent, the last census having been conducted in 2001 and the next, planned but postponed since 2012, now due in 2016.

It is important to note that this volume not only refers to literature in English, but gives equal attention to research published in Ukrainian and Russian, as well as Italian, Greek, Portuguese, Czech, Polish and Spanish. The use of Ukrainian- and Russian-language sources in particular is a long-delayed gesture of recognition of the important contributions of Ukrainian- and Russian-speaking scholars and hopefully can help facilitate more direct dialogue with Ukrainian scholars.

Each chapter in the volume provides its concluding remarks and maps out the further development of the research in their area. However, we deliberately leave the reader without a concluding chapter, but a chapter that serves as a concluding vignette, offering an ethnographic perspective on comparative research into Ukrainian mobility to the EU and the USA.

We hope this volume can serve as a knowledge production map that facilitates scholars in various disciplines to see the bigger picture in this generally disconnected research area and helps identify spaces of critical interventions and collaborative research. At a time when both Ukraine, with its current political and military crisis, and the EU, seem to be sinking ever deeper into an ideological and political coherence crisis, we would like the book to be seen as a watershed, enabling the inquiry on mobility from Ukraine to the EU to continue in a more integrated way. 


\section{References}

Akalin, A. (2007). Hired as caregiver, demanded as a housewife. Journal of Women's Studies, 14(3), 209-225.

Al-Haj, M. (2002). Identity patterns among immigrants from the former Soviet Union in Israel: Assimilation vs. ethnic formation. International Migration, 40(2), 49-70.

BAMF (Federal Office for Migration and Refugees). (2012a). Das Bundesamt in Zahlen 2011. Asyl, Migration, ausländische Bevölkerung und Integration. Zahlen 2011, Nürnberg: BAMF.

BAMF (Federal Office for Migration and Refugees). (2012b). Das Migrationspotenzial aus der GUS in die Europäische Union. Research Report 17, Nürnberg: BAMF.

Bedezir, V. (2001). Migration from Ukraine to Central and Eastern Europe. In C. Wallace \& D. Stola (Eds.), Patterns of migration in Central Europe (pp. 277-291). Basingstoke: Palgrave.

Ben-Rafael, E., Olshtain, E., \& Geijst, I. (1998). Identity and language: The social insertion of Soviet Jews in Israel. Immigration to Israel (pp. 333-356).

BMI (Federal Ministry of the Interior). (2004). Migrationsbericht im Auftrag der Bundesregierung. Migrationsbericht 2004. Berlin: BMI.

BMI (Federal Ministry of the Interior). (2011). Migration und Integration. Aufenthaltsrecht, Migrations- und Integrationspolitik in Deutschland. Berlin: BMI.

BMI (Federal Ministry of the Interior). (2013). Migrationsbericht des Bundesamtes für Migration und Flüchtlinge im Auftrag der Bundesregierung. Migrationsbericht 2011. Berlin: BMI.

Bpb (Bundeszentrale für politische Bildung). (2011). Die soziale Situation in Deutschland, (Spät-) Aussiedler. Zahlen und Fakten. 28.11.2012. http://www.bpb.de/nachschlagen/zahlen-undfakten/soziale-situation-in-deutschland/61643/aussiedler.

Černík, J. (2006). Of Clients and Chereps. The organisational structures of Ukrainian Labour Migration. In A. Szczepaniková, M. Čaněk \& J. Grill (Eds.), Migration processes in Central and Eastern Europe: Unpacking the diversity (pp. 25-29). Prague: Multikulturní centrum Praha. http://aa.ecn.cz/img_upload/79a33131c9c4293e0fcefb50bfa26 3ef/Migration_Processes_in_CEE_hq.pdf

Couton, P. (2013). The impact of communal organizational density on the labour market integration of immigrants in Canada. International Migration, 51(1), 92-114.

Destatis (Federal Statistical Office). (2012). Bevölkerung und Erwerbstätigkeit. Bevölkerung mit Migrationshintergrund. Ergebnisse des Mikrozensus 2011. Series 1, Number 2.2, Wiesbaden: Statistisches Bundesamt.

Golbert, R. L. (2001). Transnational orientations from home: Constructions of Israel and transnational space among Ukrainian Jewish youth. Journal of Ethnic and Migration Studies, 27(4), 713-731.

Hudyma, K. (2011). Ukrainian language in Canada: From prosperity to extinction? Working Papers of the Linguistics Circle of the University of Victoria, 21(1), 181-189.

Içduygu, A. (2006). A panorama of the international migration regime in Turkey. Revue Européenne des Migrations Internationales, 22(3), 11-21.

Içduygu, A. (2013). Turkey and international migration 2012-2013. Report prepared for the annual meeting of the OECD Expert Group on Migration, Paris, 27-29 November 2013. https://mirekoc.ku.edu.tr/sites/mirekoc.ku.edu.tr/files/FINAL_OECDMigration RTurkey2012-13.pdf. Accessed 10 Nov 2015.

Kimmerling, B. (1998). The new Israelis: Multiple cultures without multiculturalism. Alpayim, 16, 263-308.

Kirişci, K. (2009). Turkey: The political and social dimension of migration. Mediterranean migration 2008-2009 report. European University Institute, Robert Schuman Centre for Advanced Studies - http://www.carim.org/publications/MMR-0809\%20-\%20Part\%204\%20-\%20 Palestine-Turkey.pdf

Libanova, E., Burakovskyj I., \& Myroshnychenko, A. (2009). Fund "Open Ukraine” has announced new data concerning Ukrainian labor migrants abroad during the round table talk entitled "Ukrainian labor migration: reality, challenges and answers". Open Ukraine. http://openukraine.org/ua/programs/migration/research-program/ 
Lopukh, V. (2006). Chetverta khvila imigracii do SSHA: prichiny i motivacii [The fourth wave of migration to USA: Reasons and motivation]. Demographiya ta socialna ekonomika [Demography and Social Economy] Vol. 2.

Makuch, A. (2002, March 10). Sociologist examines latest wave of Ukrainian immigration to Canada. The Ukrainian Weekly, LXX(10).

Makuch, A. (2003, March 30). Ukrainian Canadians in the 2001 Census: An overview. The Ukrainian Weekly, LXXI(13).

MPC. (2013). Ukraine. Migration Profile. Migration Policy Centre. www.migrationpolicycentre. $\mathrm{eu}$

Shulga, N. (2002). Velikoepereselenie: repatrianty, bezhentsy, trudovyemigranty. [The great resettlement of peoples: Repatriates, refugees, labor migrants]. Kiev: Institutsotsologiy NAN Ukrainy

Shybko, V., Khomra, O., Ozhevan, M., \& Prymak, O. (Eds.). (2006). Trudova mihratsija hromadjan Ukrajiny, [Labor migration of Ukrainian Citizens]. Kyiv: Kyjivskyj Universytet.

Sylina, T. (2008). Na rekakh vavilonskikh (On Babylonian rivers) -2. Zerkalonedeli [Weekly Mirror].

Tegeler, V., \& Cherkez, O. (Eds.). 2011. Ukrainian labour migration processes in Russia: Social and gender aspects. Materials of a comprehensive sociological study. Odessa: TOB "Elton".

Walsh, S. D., \& Tartakovsky, E. (2011). The relationship between different components of national identities and psychological adjustment among high-school adolescent immigrants from Russia and Israel in Ukraine. The European Journal of Developmental Psychology, 8(4), 452-472.

Wirz, Y. (unpublished). Ukrainian migration to Germany: Diverse but little seen. Country Report.

Wolowyna, O. (2010). Some consequences of the new wave immigration from Ukraine for the Ukrainian diaspora in the United States. Paper presented at the 3rd international scientificpractical conference. Lviv: International Institute of Education, Culture and Relations with Ukraine.

Wolowyna, O. (2013). Effects of the 4th wave immigration on the language situation of persons of Ukrainian ancestry in the United States. Paper presented at the 4th international scientificpractical conference. Lviv: International Institute of Education, Culture and Relations with Ukraine.

Open Access This chapter is distributed under the terms of the Creative Commons AttributionNoncommercial 2.5 License (http://creativecommons.org/licenses/by-nc/2.5/) which permits any noncommercial use, distribution, and reproduction in any medium, provided the original author(s) and source are credited.

The images or other third party material in this chapter are included in the work's Creative Commons license, unless indicated otherwise in the credit line; if such material is not included in the work's Creative Commons license and the respective action is not permitted by statutory regulation, users will need to obtain permission from the license holder to duplicate, adapt or reproduce the material. 